\title{
Platelet Surface Glycoproteins \\ Studies on Resting and Activated Platelets and Platelet Membrane Microparticles in Normal Subjects, and Observations in Patients during Adult Respiratory Distress Syndrome and Cardiac Surgery
}

\author{
James N. George, * Elaine B. Pickett, ${ }^{*}$ Sherry Saucerman, ${ }^{*}$ Rodger P. McEver, $¥$ Thomas J. Kunicki,\$ \\ Nelly Kieffer, $\|$ and Peter J. Newman\$ \\ Division of Hematology, Department of Medicine, ${ }^{*}$ and Department of Cellular and Structural Biology, $\ddagger$ University of Texas Health \\ Science Center, San Antonio, Texas 78284; \$Blood Center of Southeastern Wisconsin, Milwaukee, Wisconsin 53233; \\ \|Unite 91, Institut National de la Santé et de la Recherche Médicale, Hôpital Henri Mondor, 94010 Creteil, France
}

\begin{abstract}
The accurate definition of surface glycoprotein abnormalities in circulating platelets may provide better understanding of bleeding and thrombotic disorders. Platelet surface glycoproteins were measured on intact platelets in whole blood and platelet membrane microparticles were assayed in cell-free plasma using ${ }^{125} I-$ monoclonal antibodies. The glycoproteins (GP) studied were: GP Ib and GP IIb-IIIa, two of the major intrinsic plasma membrane glycoproteins; GMP-140, an $\alpha$-granule membrane glycoprotein that becomes exposed on the platelet surface following secretion; and thrombospondin (TSP), an $\alpha$-granule secreted glycoprotein that rebinds to the platelet surface. Thrombin-induced secretion in normal platelets caused the appearance of GMP-140 and TSP on the platelet surface, increased exposure of GP IIb-IIIa, and decreased antibody binding to GP Ib. Patients with adult respiratory distress syndrome had an increased concentration of GMP-140 and TSP on the surface of their platelets, demonstrating in vivo platelet secretion, but had no increase of platelet microparticles in their plasma. In contrast, patients after cardiac surgery with cardiopulmonary bypass demonstrated changes consistent with membrane fragmentation without secretion: a decreased platelet surface concentration of GP Ib and GP IIb with no increase of GMP-140 and TSP, and an increased plasma concentration of platelet membrane microparticles. These methods will help to define acquired abnormalities of platelet surface glycoproteins.
\end{abstract}

\section{Introduction}

Membrane surface glycoproteins are critical for normal platelet adhesion to the vessel wall and subsequent platelet aggregation, and their abnormalities associated with congenital bleeding disorders have been well described (1). In contrast, the definition of acquired disorders of platelet membrane glycoproteins has been less clear (2-7). Changes of surface glycoproteins may occur in circulating platelets that could increase the risk for bleeding or thrombosis: plasma membrane microparticles can be lost, causing a decreased concentration of intrinsic plasma membrane

Address reprint requests to Dr. George, Division of Hematology, Department of Medicine, University of Texas Health Science Center, 7703 Floyd Curl Drive, San Antonio, TX 78284.

Received for publication 10 December 1985 and in revised form 17 March 1986.

J. Clin. Invest.

(c) The American Society for Clinical Investigation, Inc.

0021-9738/86/08/0340/09 \$1.00

Volume 78, August 1986, 340-348 glycoproteins (8-12); the microparticles themselves may accumulate in the plasma; $\alpha$-granule membrane proteins can become exposed on the platelet surface following secretion (13-15); and large, contact-promoting $\alpha$-granule secreted proteins can rebind to the cell surface (16-21). In contrast to the more severe and uniform membrane abnormalities seen in congenital platelet defects, the membrane changes in acquired disorders may be transient and less severe. A major problem in detecting acquired disorders may be the susceptibility of platelets to membrane alterations during isolation procedures used for previous methods of analysis (22) that could obscure minor glycoprotein abnormalities or cause the loss of an abnormal platelet subpopulation. The measurement of platelet surface glycoproteins directly in immediately fixed whole blood samples with ${ }^{125}$ I-labeled monoclonal antibodies (23) overcomes the risks from these in vitro artefacts. We have adapted this method to define the pattern of platelet membrane changes caused by in vitro thrombin-induced secretion, and the microparticle changes caused by whole blood coagulation. These changes were then compared to the patterns of platelet surface glycoprotein abnormalities in patient groups in which the occurrence of platelet abnormalities was suspected: adult respiratory distress syndrome (ARDS) and cardiopulmonary bypass surgery.

\section{Methods}

Antibodies. The following monoclonal antibodies were used for these studies: AP-1, that reacts with the glycocalicin moiety of glycoprotein (GP) Ib ${ }^{1}$ (23-25); three antibodies that react with GP IIb-IIIa: T10, that recognizes the intact GP IIb-IIIa complex (26), Tab, that reacts with GP IIb $(26,27)$, and AP-3, that reacts with GP IIIa (28); S12, that reacts with the $\alpha$-granule membrane glycoprotein GMP-140 $(13,15)$; and 5G11, that reacts with thrombospondin (29). These antibodies were purified from ascites fluid by ammonium sulfate precipitation and DEAE-cellulose chromatography (27), then frozen in aliquots at $-70^{\circ} \mathrm{C}$.

Antibodies were radiolabeled after centrifugation at $150,000 \mathrm{~g}$ for 10 min in a Beckman airfuge (Beckman Instruments, Inc., Fullerton, CA) with [ $\left.{ }^{125} \mathrm{I}\right] \mathrm{NaI}$ and Enzymobeads (Bio-Rad Laboratories, Richmond, $\mathrm{CA}$ ) and the radiolabeled protein was separated from free [ $\left.{ }^{125} \mathrm{I}\right] \mathrm{NaI}$ by gel filtration on a Pharmacia PD-10 column containing Sephadex G25M (Pharmacia, Piscataway, NJ). The specific activity of the protein was $1,000-2,000 \mathrm{cpm} / \mathrm{ng}$ and $>99 \%$ of the radioactivity was precipitated by $8 \%$ trichloroacetic acid. After the protein concentration of the labeled antibody was determined, bovine serum albumin (BSA) $(0.35 \%)$ and sodium azide $(0.02 \%)$ were added and the solution stored at $4^{\circ} \mathrm{C}$. Aliquots of antibody were centrifuged at $150,000 \mathrm{~g}$ for $10 \mathrm{~min}$ immediately before their use in binding experiments.

1. Abbreviations used in this paper: ARDS, adult respiratory distress syndrome; GP, glycoprotein; GMP, granule membrane protein; PGE $_{1}$, prostaglandin $\mathrm{E}_{1}$; TSP, thrombospondin. 
Measurement of platelet surface glycoproteins in whole blood samples. Blood samples were obtained with informed consent from normal volunteers and patients by our published methods (22), except where indicated. All assays were performed on the same day the sample was obtained unless otherwise noted. For analyses of GP Ib, GP Ilb, and GMP-140, $1.5 \mathrm{ml}$ of blood was drawn into an equal volume of $10 \mathrm{mM}$ EDTA, $0.2 \%$ glutaraldehyde (grade II, Sigma Chemical Co., St. Louis, $\mathrm{MO}$ ), and $0.02 \%$ sodium azide in phosphate-buffered saline (PBS) on ice. Fixed samples were diluted to $10^{7}$ platelets $/ \mathrm{ml}$ in Tyrode's buffer (138 mM NaCl, $29 \mathrm{mM} \mathrm{KCl}, 12 \mathrm{mM} \mathrm{NaHCO}_{3}, 0.4 \mathrm{mM} \mathrm{NaHPO}_{4}, 0.1 \%$ glucose, and $0.35 \% \mathrm{BSA}$ ), $\mathrm{pH} 7.4$, with $5 \mathrm{mM}$ EDTA. For assay of thrombospondin (TSP), $50 \mathrm{mM} \mathrm{MgCl}{ }_{2}$ was substituted for the EDTA in the anticoagulant-fixative solution and the Tyrode's diluting buffer contained $2 \mathrm{mM} \mathrm{CaCl}{ }_{2}$ instead of EDTA. The use of $\mathrm{MgCl}_{2}$ as an anticoagulant was originally described by Crawford. ${ }^{2}$ To $250 \mu \mathrm{l}$ of the diluted whole blood sample, containing $2.5 \times 10^{6}$ platelets, was added $200 \mu \mathrm{l}$ of $0.05 \mathrm{M}$ Tris, $0.10 \mathrm{M}$ glycine (to neutralize excess glutaraldehyde), $\mathrm{pH}$ 7.4 , and $50 \mu \mathrm{l}$ of the Tyrode's diluting buffer containing $0.5 \mu \mathrm{g}$ of radioiodinated monoclonal antibody. After a 30-min incubation at room temperature, samples were centrifuged at $12,000 \mathrm{~g}$ for $5 \mathrm{~min}$ and the platelets were washed twice with $1 \mathrm{ml}$ of Tyrode's diluting buffer at $12,000 \mathrm{~g}$ for $5 \mathrm{~min}$ without attempting to resuspend the pellet. The radioactivity of the pellet was measured and the data were expressed as molecules of glycoprotein antigen per platelet. It was assumed that only one molecule of antibody bound to each molecule of antigen; however, because TSP is a trimeric glycoprotein $(30,31)$, antibody binding may have overestimated the number of molecules of TSP exposed on the platelet surface. All samples were performed in triplicate. In initial experiments, the separation of platelets from unbound ${ }^{125}$ I-antibody by this washing method was compared with separation performed by layering the $0.5-\mathrm{ml}$ reaction mixture on $1.0 \mathrm{ml}$ of $20 \%$ sucrose in PBS $(28,32)$ and centrifuging the samples at $12,000 \mathrm{~g}$ at room temperature for $5 \mathrm{~min}$. The supernatant fluid above the cell pellet was aspirated and the counts per minute bound to the pellet were measured after cutting off the tube tip.

Measurement of surface glycoproteins on red blood cells and white blood cells. Red cells were isolated from blood defibrinated with glass beads at $37^{\circ} \mathrm{C}$ to diminish platelet contamination. To obtain white cells, defibrinated blood was mixed with 10 vol of $150 \mathrm{mM} \mathrm{NH}_{4} \mathrm{Cl}$ at room temperature for $10 \mathrm{~min}$ and the resulting hemolysate centrifuged at 150 $g$ for $6 \mathrm{~min}$ (33). After two washes at $150 \mathrm{~g}$ for $6 \mathrm{~min}$, no platelets were seen on a stained smear and the white cell differential count was equal to a count of the original whole blood. Antibody binding studies were performed as described for platelets, using $2.5 \times 10^{6}$ cells in the presence of either $5 \mathrm{mM}$ EDTA or $2 \mathrm{mM} \mathrm{CaCl}$.

Measurement of surface glycoproteins on human endothelial cells. Endothelial cells were isolated from umbilical cords by the method of Jaffe et al. (34) using 0.05\% collagenase (139 U/mg, Cooper Biomedical, Malvern, PA). The endothelial cells were washed once in Tyrode's buffer, then $2.5 \times 10^{6}$ cells were assayed together with $2.5 \times 10^{6}$ platelets in whole blood anticoagulated with either EDTA or $\mathrm{MgCl}_{2}$.

Measurement of platelet surface proteins on washed platelets to study the effect of thrombin. Blood was collected into one-fifth volume of acid citrate dextrose $(\mathrm{ACD})$ containing $300 \mathrm{ng} / \mathrm{ml}$ prostaglandin $\mathrm{E}_{1}\left(\mathrm{PGE}_{1}\right)$ (22), the platelets were washed twice in Tyrode's buffer, $\mathrm{pH} 6.5$, containing $50 \mathrm{ng} / \mathrm{ml} \mathrm{PGE}_{1}(22,35)$ but with no $\mathrm{CaCl}_{2}$ or EDTA, and then resuspended to $10^{8} / \mathrm{ml}$ in Tyrode's-PGE ${ }_{1}, \mathrm{pH} 7.4$, containing either $2 \mathrm{mM}$ $\mathrm{CaCl}_{2}$ or $5 \mathrm{mM}$ EDTA. Human $\alpha$-thrombin $(2,600 \mathrm{U} / \mathrm{mg}$, a gift from Dr. John W. Fenton, New York State Department of Health, Albany, $\mathrm{NY}$ ) was added to a final concentration of $1.0 \mathrm{U} / \mathrm{ml}$ (in control samples, thrombin was omitted) and the samples were mixed once by inversion and incubated undisturbed at $37^{\circ} \mathrm{C}$ for $10 \mathrm{~min}$, to prevent aggregation in the $\mathrm{Ca}^{2+}$-containing samples. After the incubation, hirudin (Sigma)

2. Crawford, $\mathrm{N}$., personal communication. The use of $\mathrm{MgCl}_{2}$ as an anticoagulant is the subject of International Patent Application No. 83/ 03830 . was added to a final concentration of $2 \mathrm{U} / \mathrm{ml}$ and the samples kept at room temperature for $5 \mathrm{~min}$, then an equal volume of $2 \%$ paraformaldehyde was added and the samples kept at room temperature for another $5 \mathrm{~min}$. Fixation of washed platelets in $0.1 \%$ glutaraldehyde caused decreased antibody binding. Samples were mixed by inversion after each addition. Antibody binding studies were performed as described above. Inactive thrombin was prepared by reaction with diisopropylphosphofluoridate (DFP) (36).

Platelet membrane microparticles. Plasma for microparticle assays, using all antibodies except for TSP, was obtained by the method of Levine and Krentz (37) for the assay of platelet factor 4: anticoagulation with EDTA $(5 \mathrm{mM})$, PGE $_{1}(1 \mu \mathrm{g} / \mathrm{ml})$, and dibutyryl-cyclic AMP $(1.0 \mathrm{mM})$ and centrifugation at $12,000 \mathrm{~g}$ for $10 \mathrm{~min}$ at $4^{\circ} \mathrm{C}$. To assay for TSP in microparticles, $\mathrm{MgCl}_{2}(25 \mathrm{mM})$ was substituted for EDTA. Serum was obtained by allowing blood to clot in a glass tube at $37^{\circ} \mathrm{C}$ for $2 \mathrm{~h}$ followed by centrifugation at $12,000 \mathrm{~g}$ for $10 \mathrm{~min}$. To measure platelet microparticles, $1 \mathrm{ml}$ of plasma or serum was incubated at room temperature for $30 \mathrm{~min}$ with $1 \mu \mathrm{g}$ of ${ }^{125} \mathrm{I}$-antibody, an amount that exceeded the saturating concentration. Duplicate samples as well as duplicate blanks of $1 \mu \mathrm{g}$ of ${ }^{125}$ I-antibody in Tyrode's buffer were assayed. Following incubation, the samples were diluted to $7.2 \mathrm{ml}$ with buffer and centrifuged at $67,000 \mathrm{~g}$ for $60 \mathrm{~min}$. The buffer was aspirated and the invisible pellet was washed once with $7.2 \mathrm{ml}$ of buffer at $67,000 \mathrm{~g}$ for $20 \mathrm{~min}$. There was no greater recovery if the forces were increased to $200,000 \mathrm{~g}$ and the times extended. Then the counts per minute remaining in the pellet were measured and expressed as molecules of antigen per milliliter of plasma or serum.

Patients. The patients in these studies were hospitalized at Medical Center Hospital or at Audie Murphy Veterans Administration Hospital, San Antonio. Patients with ARDS were enrolled in our institutional study of this disease (38). Cardiac surgery patients were studied during cardiopulmonary bypass with a bubble oxygenator for coronary artery bypass grafting (six patients), repair of ventricular septal defect (one), mitral valve replacement (one), and aortic valve replacement (one). To study blood collection methods, simultaneous samples were drawn by venipuncture and through acutely placed peripheral arterial catheters (five patients being prepared for elective surgery) and pulmonary artery catheters (nine patients undergoing cardiac catheterization) as well as chronic central venous and arterial catheters that had been in place for 4-6 wk (two patients).

Statistical analyses were performed using Student's $t$ test (39).

\section{Results}

\section{Normal platelets}

PLATELET SURFACE GLYCOPROTEINS. The antibody binding assay. The recovery of ${ }^{125} \mathrm{I}$-antibody bound to platelets in whole blood or to washed, thrombin-treated platelets was the same when platelets were separated from unbound antibody either by three washes or by centrifugation through $20 \%$ sucrose. This demonstrated that the wash procedure did not trap unbound antibody or remove bound antibody or surface-bound TSP. The slow dissociation rate of the four antibodies used (AP-1, Tab, $\mathrm{S} 12$, and $5 \mathrm{G} 11$ ) was demonstrated by the addition of 50 -fold excess cold antibody at the end of the 30 -min binding incubation followed by an additional 10-min incubation before the washing steps. Less than $5 \%$ of the bound ${ }^{125}$ I-labeled antibodies was displaced. Similar irreversibility of a monoclonal antibody (AP2) binding to GP IIb-IIIa has been reported previously (32). Analyses of AP-1 and Tab-binding in whole blood and for S12binding to thrombin-treated washed platelets indicated that an antibody concentration of $1 \mu \mathrm{g} / \mathrm{ml}$ bound to $85-90 \%$ of the total calculated surface glycoprotein molecules. Analysis of 5G11 binding to thrombin-treated platelet suspensions not separated from soluble, secreted TSP, demonstrated that less than half of 
the total calculated surface molecules were detected with $1 \mu \mathrm{g} /$ $\mathrm{ml}$ of antibody and $80 \%$ with $10 \mu \mathrm{g} / \mathrm{ml}$. In spite of the underestimate of platelet surface TSP molecules by $1 \mu \mathrm{g} / \mathrm{ml}$ of antibody, this method allowed a clear distinction between thrombintreated and control platelets (washed thrombin treated: $19,323 \pm 9,028$ [SD] molecules TSP per platelet, $n=11$; washed control incubated: $1,955 \pm 369$ molecules TSP per platelet, $n=6$, $P<0.001)$. In subsequent studies of patient samples, high platelet surface concentrations of TSP measured in whole blood samples, that may also have contained high plasma concentrations of TSP, correlated well with high concentrations of GMP-140 on the platelet surface (see Fig. 3).

The platelet membrane glycoprotein values obtained in normal whole blood samples using this method were: GP Ib $=26,052 \pm 5,367(\mathrm{SD}, n=47), \mathrm{GP}$ IIb $=52,926 \pm 8,485(n=49)$, GMP-140 = 1,187 $\pm 636(n=30)$, and TSP $=681 \pm 360(n=8)$.

Platelet specificity of antibody binding: studies on red blood cells, white blood cells, and umbilical vein endothelial cells. Membrane proteins similar to GP IIb-IIIa are found in white blood cells (40) and endothelial cells $(41,42)$; TSP is synthesized and secreted by monocytes (43) and endothelial cells (44); and GMP-140 is present in endothelial cells (45). Therefore in whole blood, these antigens may not be only derived from platelets. Previous studies in whole blood from patients with BernardSoulier syndrome (23) and Glanzmann's thrombasthenia (unpublished observation) have demonstrated no binding of AP-1 and Tab, respectively, suggesting platelet specificity. Peripheral blood white blood cells isolated under conditions of maximal thrombin activation bound negligible amounts of AP-1, S12, and $5 \mathrm{G} 11$, and $<10 \%$ as much $\mathrm{Tab}$ as an equal number of platelets. Red cells demonstrated no antibody binding. Endothelial cells did not bind AP-1, Tab, and 5G11, but they did bind significant amounts of $\mathrm{S} 12$ per cell. However, since circulating endothelial cells, even in a concentration equal to $1 \%$ of platelets, is an unlikely event $(46,47)$, their contribution to $S 12$ binding in a whole blood assay should be negligible. Also in our studies with thrombin activation and patient samples, increased binding of S12 and 5G11 was parallel (Figs. 1 and 3), which is another distinction from endothelial cells. The production of microparticles by sonication of isolated white blood cells and endothelial cells $\left(10^{6} / \mathrm{ml}\right)$ did not contribute significantly to the concentration of platelet microparticles measured by Tab binding.

Fixation and storage of whole blood samples. There was no difference in binding of the monoclonal antibodies to platelets in whole blood that were unfixed or fixed with glutaraldehyde, if the assays were performed immediately after collection. However, if there was a delay of $4 \mathrm{~h}$ at room temperature before fixation, there was decreased antibody binding to GP Ib (42\%) and increased binding to GP IIb (11\%) and GMP-140 (3.6-fold). These changes suggest that a low concentration of thrombin is formed, sufficient to stimulate platelet secretion but not enough to cause coagulation (48). Standing at $4^{\circ} \mathrm{C}$ prevented the changes with GP Ib and GMP-140, but not the change in GP IIb. Adding $\mathrm{PGE}_{1}(1 \mu \mathrm{g} / \mathrm{ml})$ and dibutyryl-cAMP $(1 \mathrm{mM})(37)$ to the anticoagulant did not prevent these changes at room temperature or $4^{\circ} \mathrm{C}$. Therefore prompt fixation of the whole blood samples was essential for accurate measurement of the platelet surface glycoproteins and glutaraldehyde was included in the anticoagulant solution of EDTA or $\mathrm{MgCl}_{2}$. Once fixed and stored at $4^{\circ} \mathrm{C}$, the surface glycoproteins were stable for $24 \mathrm{~h}$.

Effect of blood collection technique. Because blood samples for clinical studies frequently cannot be satisfactorily obtained by a venipuncture, the effect of collecting blood through indwelling catheters was studied. Blood collection through arterial or venous catheters that had been placed acutely or had been in place for up to 6 wk caused no change of the membrane glycoprotein measurements on intact platelets in whole blood or in platelet membrane microparticles. The difference from simultaneous samples obtained by our routine venipuncture technique was always $<10 \%$. This is different from the significant artefactual elevation of plasma concentrations of platelet factor 4 in samples collected through indwelling needles (49). Only $1 \%$ platelet secretion, however, not noticeable in our assay, would cause a 30-fold increase of the plasma level of platelet factor 4 (37).

Selection of the anticoagulant. EDTA anticoagulant was used to provide maximal inhibition of platelet activation (37) as well as inhibition of the endogenous platelet calcium-dependent protease that can hydrolyze GP Ib $(50,51)$. However, a large fraction of TSP that rebinds to the platelet surface following secretion is dependent on the presence of $\mathrm{Ca}^{2+}(17,20)$. Table I demonstrates that almost all of the platelet surface-bound TSP is lost from the platelet during calcium chelation even when formaldehyde is simultaneously present. To detect circulating platelets that may have TSP bound to their surface membrane, therefore, a different anticoagulant was required and $25 \mathrm{mM} \mathrm{MgCl}$ was selected because it caused no loss of platelet surface bound TSP. While assays for GP Ib, GP IIb, and GMP-140 were the same in normal whole blood samples anticoagulated with either $\mathbf{M g C l}_{\mathbf{2}}$ or EDTA, EDTA was used for these assays because of its familiarity and known mechanism of anticoagulant action. Although the mechanism of anticoagulation by $25 \mathrm{mM} \mathrm{MgCl}_{2}$ is unknown, it is clear from several observations that higher concentrations of $\mathrm{Ca}^{2+}$ or $\mathrm{Mg}^{2+}$ are able to inhibit reactions that require lower concentrations of these ions. An early study of clotting times after recalcification of blood anticoagulated with 10 or $20 \mathrm{mM}$ sodium citrate demonstrated the shortest times with calcium concentrations of 45-74 mM (52). Either lower or

Table I. Platelet Surface TSP Following

Thrombin-induced Secretion: The Effect of EDTA, Citrate, and $\mathrm{MgCl}_{2}$ Anticoagulation

\begin{tabular}{lc}
\hline Platelet preparation & Platelet surface TSP \\
\hline & molecules/platelet \\
Control platelets & 1,763 \\
Thrombin-treated platelets $(5 \mathrm{mM} \mathrm{EDTA})$ & 3,914 \\
Thrombin-treated platelets $\left(2 \mathrm{mM} \mathrm{Ca}{ }^{2+}\right)$ & \\
+ formaldehyde + buffer & 27,484 \\
+ formaldehyde + $5 \mathrm{mM} \mathrm{EDTA}$ & 2,212 \\
+ formaldehyde $+130 \mathrm{mM}$ citrate & 3,948 \\
+ formaldehyde $+25 \mathrm{mM} \mathrm{MgCl}$ & 27,101 \\
& \\
\end{tabular}

The data are the mean values of 1-5 experiments. Washed platelets were resuspended with either $5 \mathrm{mM}$ EDTA or $2 \mathrm{mM} \mathrm{Ca}^{2+}$ for thrombin treatment. Control platelets were resuspended with EDTA. After incubation for $10 \mathrm{~min}$ at $37^{\circ} \mathrm{C}$ with or without thrombin $(1 \mathrm{U} / \mathrm{ml})$ followed by hirudin neutralization, all samples were fixed with formaldehyde before assays for platelet surface TSP were performed. Some $\mathrm{Ca}^{2+}$ samples were fixed with formaldehyde containing EDTA, sodium citrate, or magnesium chloride, to achieve the final concentrations shown above. 
higher concentrations resulted in longer clotting times. Also ADP-induced fibrinogen binding to the platelet surface (53) and ADP-induced platelet aggregation (54) require low concentrations of $\mathrm{Ca}^{2+}$ or $\mathrm{Mg}^{2+}$ but are inhibited by higher concentrations.

Effect of thrombin treatment on platelet surface glycoprotein. Measurements of GP Ib are presented only for incubations in EDTA-containing buffer, because fewer GP Ib sites were measured following control incubations in the presence of $\mathrm{Ca}^{2+}$ containing buffer $(13,868$ molecules per platelet, $n=3$, versus $19,541 \pm 5,140$ [SD], $n=10$, for $\mathrm{Ca}^{2+}$ and EDTA, respectively), possibly due to loss of glycocalicin by activity of the calciumdependent protease $(50,51)$. Even with EDTA the values for GP Ib on washed control incubated platelets were less than for the immediately fixed whole blood samples $(P<0.001)$. Measurements of GP IIb with ${ }^{125} \mathrm{I}-\mathrm{Tab}$ are presented only for incubations in $\mathrm{Ca}^{2+}$-containing buffer, because in the presence of EDTA fewer GP Ilb sites were measured following control incubations $(48,094 \pm 4,694, n=5$, vs. $36,943 \pm 7,703, n=14, P$ $<0.01$, for $\mathrm{Ca}^{2+}$ and EDTA, respectively), possibly due to GP IIb aggregates formed by incubation at $37^{\circ} \mathrm{C}$ in the presence of EDTA $(55,56)$. In $\mathrm{Ca}^{2+}$-buffer, the values for GP IIb were the same on washed control incubated platelets as on platelets in immediately fixed whole blood samples $(P>0.8)$. Measurements of the GP IIb-IIIa complex using ${ }^{125}$ I-labeled T10 were also performed in $\mathrm{Ca}^{2+}$-buffer. The values for GMP-140 in washed control incubated platelets in either $\mathrm{Ca}^{2+}$ - or EDTA-buffers $(1,126 \pm 647, n=15)$ were the same as for whole blood samples $(1,187 \pm 636, n=30)$. Only $\mathrm{Ca}^{2+}$ containing buffer was used for TSP studies and the values for TSP sites on the washed control incubated platelets $(1,955 \pm 369, n=6)$ were greater than for whole blood samples $(681 \pm 360, n=8, P<0.001)$.

Fig. 1 demonstrates the effect of thrombin treatment on platelet surface glycoproteins. There was a marked decrease in antibody binding to GP Ib after thrombin treatment, with a loss of $60 \%$ of antigen sites on the platelet surface. This effect depended on active thrombin, as incubation with DFP-thrombin had no effect in two experiments $(24,174$ vs. 23,411 molecules/ platelet for control and DFP-thrombin-treated platelets, respec-
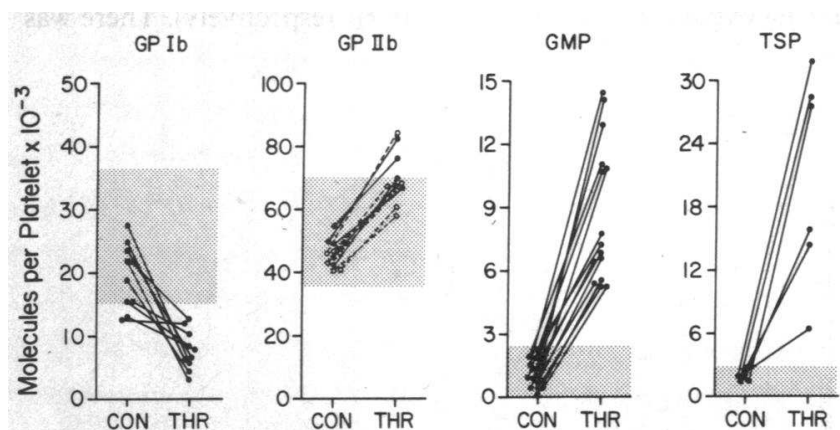

Figure 1. Effect of thrombin on platelet surface glycoproteins. Washed platelets were resuspended for thrombin treatment in buffer containing either $5 \mathrm{mM} \mathrm{EDTA}$, for assay of $\mathrm{GP} \mathrm{Ib}$, or $2 \mathrm{mM} \mathrm{CaCl}_{2}$, for assay of GP IIb and TSP. Data for GMP-140 were obtained from samples containing either EDTA or $\mathrm{CaCl}_{2}$. The shaded areas represent the normal values (mean \pm 2 SD) obtained in whole blood samples. For GP IIb, two different monoclonal antibodies were used: the solid circles and lines represent experiments with Tab; the open circles and broken lines represent experiments with T10. Thrombin treatment caused decreased antibody binding to GP Ib and increased antibody binding to GP IIb (Tab), GP IIb-IIIa (T10), GMP-140, and TSP (all $P$ values $<0.001$ ). tively). The dissociation constant $\left(K_{\mathrm{d}}\right)$ of AP-1 binding to GP Ib on thrombin-treated platelets $(0.37 \mathrm{nM}, n=2)$ was similar to untreated control platelets $(0.47 \mathrm{nM}, n=4)$. This decrease of AP-1 binding did not represent an actual loss of GP Ib molecules from platelets, since measurement of the total content of GP Ib in Triton X-100-solubilized platelets by electroimmunoassay using AP-1 (57) was equal in thrombin-treated and control platelets (unpublished observation). The decreased antibody binding to GP Ib after thrombin treatment was not reversible: if thrombin was neutralized by hirudin and the $37^{\circ} \mathrm{C}$ incubation continued for an additional $50 \mathrm{~min}$ at $37^{\circ} \mathrm{C}$, antibody binding to GP Ib remained low and unchanged. In contrast to the decreased antibody binding to GP Ib, antibody binding to GP IIbIIIa increased after thrombin treatment. Antibody binding to both GMP-140 and TSP was markedly increased. Exposure of GMP-140 was the same in the presence of $\mathrm{Ca}^{2+}(8,114 \pm 2,964$ molecules per platelet, $n=12)$ or EDTA $(8,870 \pm 3,169$ molecules per platelet, $n=18, P>0.5$ ). If thrombin was neutralized by hirudin and the $37^{\circ} \mathrm{C}$ incubation continued for an additional $50 \mathrm{~min}$, a time that allows internalization of most of the exposed secretory granule membrane protein in adrenal medulla chromaffin cells (58), there was no selective internalization of GMP140 from the cell surface (Table II). Some loss of GMP-140 and GP IIb (7-14\%) occurred equally in both control and thrombintreated samples, presumably due to membrane fragment loss during the buffer incubation.

PLATELET MEMBRANE MICROPARTICLES. Glycoprotein characterization of microparticles from plasma and serum. The GP IIb-IIIa complex was intact on the plasma microparticles as judged by the equal results using monoclonal antibodies that react with isolated GP IIb, isolated GP IIIa, or the GP IIb-IIIa complex (Table III). The microparticle GP IIb-IIIa complex was stable in EDTA when the plasma was kept at room temperature. Plasma microparticles (measured as GP IIb-IIIa) were equivalent to about $4 \times 10^{5}$ platelets $/ \mathrm{ml}$, or about $0.1 \%$ of the platelet GP IIb-IIIa contained in whole blood. No microparticles were recovered from plasma treated with $1 \%$ Triton X-100, demonstrating their lipoprotein nature. The amount of GP Ib on the microparticles in plasma was relatively less than on intact platelets. GMP-140 and TSP were not detectable in plasma micro-

Table II. Platelet Surface Concentration of GMP-140 and GP IIb after Thrombin Treatment followed by Inactivation with Hirudin and Subsequent Incubation

\begin{tabular}{llll}
\hline GP & Incubation & Thrombin & Control \\
\hline \multirow{4}{*}{ GMP-140 } & min & GP molecules/platelet & GP molecules/platelet \\
& 10 & 5,192 & 2,142 \\
GP IIb & 60 & $4,832(93 \%)$ & $1,846(86 \%)$ \\
& 10 & 73,010 & 45,584 \\
& 60 & $64,580(88 \%)$ & $40,116(88 \%)$
\end{tabular}

The data are the mean values from three experiments. Washed platelets were incubated with thrombin $(1.0 \mathrm{U} / \mathrm{ml})$ for $10 \mathrm{~min}$ in the presence of $2 \mathrm{mM} \mathrm{CaCl}_{2}$, as described in Methods. In control samples, thrombin was omitted. After $10 \mathrm{~min}$, thrombin was inactivated by the addition of $2 \mathrm{U} / \mathrm{ml}$ hirudin and an aliquot was assayed. Incubation was continued for an additional $50 \mathrm{~min}$ after which another assay was performed. The figures in parentheses are the percentages of surface antigen present at $60 \mathrm{~min}$ that were originally present after $10 \mathrm{~min}$ of incubation. 
Table III. Glycoproteins on Platelet Membrane Microparticles Isolated from Normal Plasma and Serum

\begin{tabular}{llc}
\hline GP & Plasma & Serum \\
\hline & molecules $/ m l \times 10^{-10}$ & molecules $/ m l \times 10^{-10}$ \\
Ib & $0.57 \pm 0.57(9)$ & $0.61 \pm 0.49(7)$ \\
IIb & $1.95 \pm 1.37(21)$ & $62.44 \pm 28.77(5)$ \\
IIIa & $1.38 \pm 0.56(5)$ & $57.08 \pm 41.76(5)$ \\
IIb-IIIa & $1.79 \pm 1.46(13)$ & $61.82 \pm 26.70(5)$ \\
GMP-140 & $0.02 \pm 0.02(8)$ & $4.00 \pm 1.84(8)$ \\
TSP & $0.05 \pm 0.11(8)$ & $0.39 \pm 0.62(8)$
\end{tabular}

The data are the mean values \pm 1 SD for the number of experiments shown in parentheses. Glycoproteins IIb and IIla were measured individually by the monoclonal antibodies Tab and AP-3, respectively, and the glycoprotein IIb-IIIa complex was measured by the monoclonal antibody $\mathrm{T} 10$. In plasma microparticles, there was no difference between GP IIb and GP IIIa concentrations $(P>0.30)$.

particles. Assay of serum after whole blood coagulation demonstrated an increased concentration of GP IIb-IIIa by 30- to 40-fold. The concentration of GP Ib in serum microparticles was the same as in plasma. In contrast to microparticles in plasma, GMP-140 and TSP were detectable on microparticles in serum.

\section{Clinical studies}

$A R D S$. Samples were obtained from 13 patients diagnosed by published criteria (38), via an intraarterial catheter at median times of $3 \mathrm{~d}$ after diagnosis and $5 \mathrm{~d}$ before death (12 patients) or $3 \mathrm{~d}$ before recovery in 1 patient. Underlying diseases were bacterial pneumonia with sepsis (10 patients) and postoperative complications including aspiration pneumonia ( 2 patients) and delerium tremens with pancreatitis (1 patient). Nine patients were thrombocytopenic; five had platelet counts of 10,000$35,000 / \mu 1$ (Fig. 2). The surface glycoprotein changes indicated that in some subjects the platelets had undergone $\alpha$-granule secretion and remained in the circulation with GMP-140 and TSP

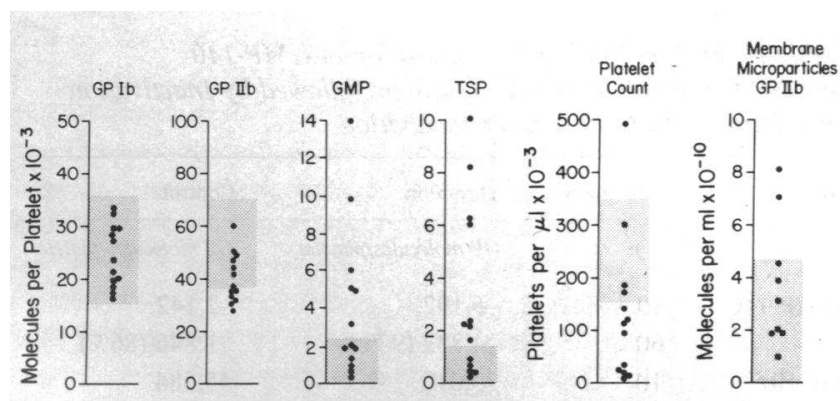

Figure 2. Platelet surface glycoproteins in patients with ARDS. 13 patients were studied with samples obtained from indwelling arterial catheters. The shaded areas represent normal values (mean $\pm 2 \mathrm{SD}$ ). Platelet surface glycoproteins were measured promptly on immediately fixed whole blood samples. Antibody binding to GP Ib was the same as with normal platelets $(P>0.40)$; antibody binding to GP IIb was decreased $(P<0.001)$; and antibody binding to GMP-140 and TSP was increased $(P<0.005, P<0.05$, respectively). Platelet membrane microparticles were measured with ${ }^{125} \mathrm{I}-\mathrm{Tab}$, a monoclonal antibody to GP IIb, in 9 of the 13 patients and the values for the group were not different from normal $(P>0.05)$. exposed on their surface. For the entire group of patients both GMP-140 and TSP were increased compared with normal control values $(P<0.005$ and $P<0.05$, respectively). Fig. 3 demonstrates the correlation between the concentrations of GMP140 and TSP on circulating platelets $(r=0.9, P<0.001)$. There was a slight correlation between the extent of platelet surface exposure of GMP-140 and TSP with the severity of thrombocytopenia $(r=-0.57, P<0.05$ and $r=-0.56, P<0.05$, respectively). The GP IIb was slightly but significantly decreased $(P<0.001)$, while GP Ib values were normal $(P>0.4)$. Platelet membrane microparticles in plasma were measured in nine subjects. Only two were elevated and the value for the group was not different from normal $(P>0.05)$. There was no apparent correlation between the patients' clinical status and the platelet abnormalities. No patient had clinically significant disseminated intravascular coagulation or any major hemorrhagic or thrombotic complications. Three patients had received platelet transfusions in the two days before our sample, and these patients had the highest values for platelet surface GMP-140 and TSP. This may only indicate a greater severity of platelet-vessel interaction, since the platelet surface GMP-140 concentration of blood bank stored platelets is normal (unpublished observations).

Cardiopulmonary bypass surgery. Blood samples were obtained from 10 patients in the operating room from their arterial catheter before cardiopulmonary bypass was initiated and again just before bypass was discontinued (Fig. 4). Cardiopulmonary bypass time averaged $74 \mathrm{~min}$ (range, $57-110 \mathrm{~min}$ ) and all patients had uncomplicated operations without excessive hemorrhage or other postoperative problems. No blood or platelet transfusions were given to any patients before or during the bypass procedure. The platelet counts decreased during the bypass procedure in all but one subject, and the plasma microparticle concentration increased in all subjects. The patient with the greatest increase in platelet membrane microparticles is the same patient whose platelet count increased. This patient had the average time of bypass ( $80 \mathrm{~min}$ ) and nothing unusual about his course. Even though all values for GP Ib and GP IIb were within or close to the normal range, the platelet concentration of both of these intrinsic plasma membrane glycoproteins decreased significantly during bypass $(P<0.02$ and $P<0.01$, respectively). There was

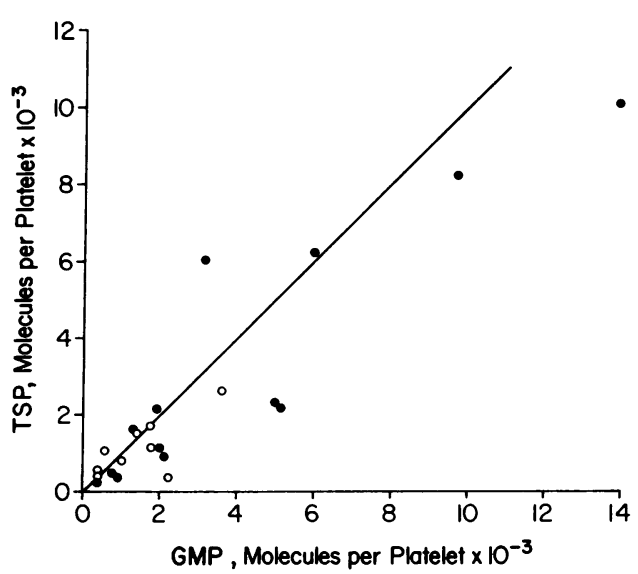

Figure 3. Correlation of exposure of GMP-140 and TSP on the platelet surface in 13 patients with ARDS (๑) and 9 patients following cardiac surgery with cardiopulmonary bypass (0). The data are taken from Figs. 2 and 4. Data on ARDS patients was $r=0.90, P<0.001$; and for the cardiac surgery patients, $r=0.93, P<0.001$. 

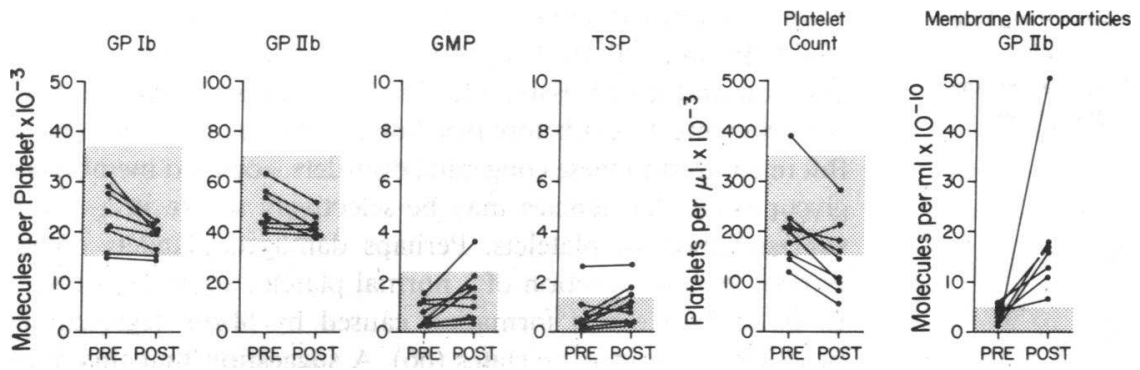

Figure 4. Platelet surface glycoproteins in patients undergoing cardiopulmonary bypass surgery. Nine patients were studied with samples obtained in the operating room from their indwelling arterial catheters before beginning bypass and again at the completion of bypass. The shaded areas represent normal values (mean \pm 2 SD). The platelet count fell significantly during the cardiopulmonary bypass procedure $(P<0.001)$. One assay for GP Ib and two for GP IIb were unsatisfactory. During the

bypass procedure, values for GP Ib and GP IIb decreased $(P<0.02$ and $P<0.01$, respectively), while values for GMP-140 and TSP did not change. Membrane microparticles were measured in seven of the nine patients, and increased significantly during the procedure $(P<0.01)$.

a significant correlation between the losses of GP Ib and GP IIb $(r=0.87, P<0.01$ ). In contrast to patients with ARDS, there was minimal evidence for platelet secretion, as neither GMP. 140 nor TSP changed significantly when analyzed for the group. One subject had abnormally high values for both GMP-140 and TSP after surgery (Figs. 3 and 4): she had less than the average cardiopulmonary bypass times $(57 \mathrm{~min})$ for a mitral valve replacement without any clinical complications. Her platelet count $(389,000$ to $280,000 / \mu 1)$ was the highest of the group and her postbypass microparticle concentration $\left(6.38 \times 10^{10}\right.$ molecules $\mathrm{GP} \mathrm{IIb} / \mathrm{ml}$ ) was the lowest of the group.

\section{Discussion}

Detection of acquired abnormalities of platelet surface proteins, that may be transient and affect only a minor fraction of circulating platelets, will require more accurate methods than have been used to define congenital abnormalities, where the platelet membrane glycoprotein deficiencies are typically uniform and severe (1). This study presents the experiments to establish sensitive assay techniques and also preliminary studies on groups of patients in whom acquired platelet abnormalities may be expected. The use of monoclonal antibodies in a whole blood assay (23) overcomes the problem of platelet selection and membrane changes caused by the usual isolation and washing procedures (22), but the specificity of reactions for platelets cannot be assumed. Our experiments with red blood cells, white blood cells, and endothelial cells, however, support the platelet specificity of these observations.

\section{Definition of platelet surface glycoprotein changes accompanying thrombin-induced secretion}

An anticipated in vivo platelet abnormality was the presence of circulating platelets that had undergone secretion. We therefore first defined the platelet membrane changes that accompany in vitro secretion stimulated by thrombin and demonstrated increased antibody binding to GMP-140, TSP, and GP IIb, and decreased binding to GP Ib. GMP-140 is an $\alpha$-granule membrane glycoprotein that becomes incorporated diffusely throughout the surface plasma membrane during secretion (15). The absence of internalization of exposed GMP-140 establishes its validity as a marker for in vivo secretion. The increase of TSP on the platelet surface was comparable to the GMP-140 exposure, both in vitro and in patient samples (Fig. 3). Ultrastructural studies have demonstrated that GP IIb-IIIa is distributed throughout the plasma membrane including the surface-connected canalicular system (D. F. Bainton, personal communication). The increased concentration of GP IIb seen after platelet stimulation with thrombin may reflect exposure of plasma membrane GP IIb that had been within the surface-connected canalicular system and inaccessible to the intact antibody molecules. Morphologic studies have demonstrated that this canalicular system is connected to the surface of resting platelets by narrow necks, which widen during platelet secretion (59). Similar increased binding of another monoclonal antibody to GP IIb-IIIa, 10E5, following platelet stimulation by thrombin has been reported previously (60). Thrombin-induced secretion caused a marked decrease of antibody binding to GP $\mathrm{Ib}$, to $40 \%$ of the resting value. The actual platelet content of GP Ib, however, as measured in solubilized platelets by electroimmunoassay with the same monoclonal antibody, was not changed. This is consistent with our earlier studies in which we found no decrease of GP Ib after thrombin-induced secretion as measured by sodium dodecyl sulfate-polyacrylamide gel electrophoresis with periodic acid Schliff staining and with radiolabeling by ${ }^{125}$ I-diazotized diiodosulfanilic acid $(16,61)$. The mechanism of this change in GP Ib is being investigated.

\section{Measurement of platelet membrane microparticles in plasma and serum}

Whole blood clotting increased the microparticle concentration 30- to 40-fold, as measured by antibody binding to GP IIb-IIIa in serum. In contrast to GP IIb-IIIa, GP Ib on microparticles was not increased in serum. Possibly the antibody epitope on glycocalicin is solubilized by proteolysis during coagulation; or it may become inaccessible to the antibody, as in thrombintreated platelets; or microparticle formation during coagulation may preferentially involve membrane domains that exclude GP Ib. Examples of membrane protein segregation during red cell membrane fragmentation (62) and platelet pseudopod formation (63) have been reported. Serum microparticles also include the membrane glycoproteins that are present on the surface of intact platelets after secretion: GMP-140 and TSP. These differences in the membrane composition of microparticles isolated from plasma and serum suggest that the formation of microparticles in normal plasma occurs by surface membrane fragmentation that does not involve coagulation and platelet secretion.

Studies on patients with adult respiratory distress syndrome and patients during cardiopulmonary bypass surgery

Abnormalities of platelet surface glycoproteins and platelet membrane microparticles in these conditions demonstrate the sensitivity of these measurements. Two patterns of abnormalities can be distinguished (Table IV).

Platelet changes resulting from secretion, with the appearance of the $\alpha$-granule membrane protein, GMP-140, and the secreted 
Table IV. Patterns of Acquired Platelet Membrane Abnormalities

\begin{tabular}{lll}
\hline & $\begin{array}{l}\text { Platelet activation and } \\
\text { secretion }\end{array}$ & $\begin{array}{l}\text { Platelet membrane } \\
\text { fragmentation }\end{array}$ \\
\hline $\begin{array}{l}\text { Intrinsic plasma } \\
\text { membrane GP }\end{array}$ & $\mathrm{N}$ or $\downarrow$ & $\downarrow$ \\
$\begin{array}{c}\text { Surface expression of } \\
\text { GMP-140 }\end{array}$ & $\uparrow$ & $\mathrm{N}$ \\
$\begin{array}{c}\text { Surface binding of TSP } \\
\text { Plasma concentration of } \\
\text { platelet membrane } \\
\text { microparticles }\end{array}$ & $\uparrow \mathrm{N}$ & $\mathrm{N}$ \\
$\begin{array}{c}\text { Example of a clinical } \\
\text { syndrome }\end{array}$ & $\begin{array}{c}\text { Adult respiratory } \\
\text { distress syndrome }\end{array}$ & $\begin{array}{c}\text { Cardiopulmonary } \\
\text { bypass surgery }\end{array}$ \\
\hline
\end{tabular}

These are interpretations of the data presented in Figs. 2 and 4.

$\alpha$-granule protein, thrombospondin, on the cell surface. Other secreted proteins may also be present on the surface of circulating platelets in these conditions but only thrombospondin was assayed. These changes could be associated with endothelial damage and result from platelet activation by thrombin. The endothelial damage and coagulation may accelerate the clearance of platelet membrane microparticles and prevent their accumulation in plasma. This pattern of platelet abnormalities was seen in patients with ARDS.

Platelet membrane fragmentation with loss of intrinsic plasma membrane glycoproteins and increased plasma concentration of membrane microparticles. In these patients there was less evidence for platelet secretion as judged by platelet surface expression of GMP-140 and TSP. This pattern was seen in patients undergoing cardiopulmonary bypass surgery that may damage platelets by increased turbulence and shear stress. A previous study of cardiopulmonary bypass surgery demonstrated platelet changes indicating $\alpha$-granule secretion that became more pronounced during the period of bypass circulation (64). Therefore the absence of evidence for $\alpha$-granule secretion in our study may be related to the shorter time on bypass of our patients (average, $74 \mathrm{~min}$ ) compared to the patients in the previous study (average, $183 \mathrm{~min}$ ). The measurements of platelet surface antigens may not reflect abnormalities of their receptor function that may also be acquired during conditions such as extracorporeal circulation (65).

Clearly these interpretations do not fit each individual patient, and the interpretation of increased or decreased values may depend on relative changes, as during cardiopulmonary bypass surgery, rather than on absolute differences from normal subjects. However, the distinction between these groups seems sufficient to suggest different mechanisms of acquired platelet membrane abnormalities.

The clinical significance of these platelet membrane abnormalities is unknown. These two groups of patients were selected because it was suspected that platelet abnormalities may occur and provide a means of evaluating new assays. It may be suspected that platelets circulating with secreted $\alpha$-granule contactpromoting proteins, such as TSP, bound to their surface may indicate an increased risk for thrombosis (1). A decreased surface concentration of GP Ib and GP IIb-IIIa may be associated with an increased risk for hemorrhage, though observations that subjects heterozygous for Bernard-Soulier syndrome and Glanz- mann's thrombasthenia, with only half normal concentrations of GP Ib and GP IIb-IIIa, respectively, have normal platelet function and no excessive bleeding (1) indicates that a severe deficiency must exist before bleeding complications could occur. But in contrast to these congenital disorders, acquired membrane glycoprotein deficiencies may be selectively severe in a small subpopulation of platelets. Perhaps damaged platelets could impede the construction of a normal platelet aggregate similar to the defective clot formation caused by fibrin degradation products in fibrinolytic states (66). A suggestion that this may occur is the observation that dogs infused with a monoclonal antibody to GP IIb-IIIa demonstrated abnormal platelet function when only a minority of GP IIb-IIIa sites were blocked (67).

\section{Acknowledgments}

We thank Dr. Lois Bready and Mrs. Nancy Raymond for assistance in patient sample collections, Drs. Neville Crawford, Jean-Philippe Rosa, Geoffrey Johnston, Shirley Levine, and Alan Nurden for advice and criticism, Mr. Adam Onofre and Mrs. Mary Torres for technical assistance, and Mrs. Judi Skinner for preparation of this manuscript.

Supported by grants from the National Heart, Lung, and Blood Institute (HL-19996, HL-32279, and HL-23578), the National Aeronautics and Space Administration (NAG-9-5), and the North Atlantic Treaty Organization (RG-113.81). Dr. Kunicki is an Established Investigator of the American Heart Association (83-186).

\section{References}

1. George, J. N., A. T. Nurden, and D. R. Phillips. 1984. Molecular defects in interactions of platelets with the vessel wall. N. Engl. J. Med. 311:1084-1098.

2. Vanier, H., and A. Bussel. 1977. Altered platelet surface glycoproteins in chronic myeloid leukemia. Int. J. Cancer. 19:143-150.

3. Bolin, R. B., T. Okumura, and G. A. Jamieson. 1977. Changes in distribution of platelet membrane glycoproteins in patients with myeloproliferative disorders. Am. J. Hematol. 3:63-71.

4. Ordinas, A., S. Maragall, R. Castillo, and A. T. Nurden. 1978. A glycoprotein I defect in platelets in three patients with severe cirrhosis of the liver. Thromb. Res. 13:297-302.

5. Wautier, J. L., M. Souchon, D. Dupuis, J. P. Caen, and A. T. Nurden. 1979. A platelet defect in a patient with eosinophilic leukemia: absent ristocetin-induced platelet aggregation associated with a reduced platelet sialic acid content. Scand. J. Haematol. 22:267-276.

6. Booth, W. J., M. C. Berndt, and P. A. Castaldi. 1984. An altered platelet granule glycoprotein in patients with essential thrombocythemia. J. Clin. Invest. 73:291-297.

7. Clezardin, P., J. L. McGregor, M. Dechavanne, and K. J. Clemetson. 1985. Platelet membrane glycoprotein abnormalities in patients with myeloproliferative disorders and secondary thrombocytosis. Br. J. Haematol. 60:331-344.

8. Wolf, P. 1967. The nature and significance of platelet products in human plasma. Br. J. Haematol. 13:269-288.

9. Crawford, N. 1971. The presence of contractile proteins in platelet microparticles isolated from human and animal platelet-free plasma. $\mathrm{Br}$. J. Haematol. 21:53-69.

10. George, J. N., P. C. Lewis, and D. A. Sears. 1976. Studies on platelet plasma membranes. II. Characterization of surface proteins of rabbit platelets in vitro and during circulation in vivo using diazotized [ ${ }^{125}$ I]ddiiodosulfanilic acid as a label. J. Lab. Clin. Med. 88:247-260.

11. George, J. N., L. L. Thoi, L. M. McManus, and T. A. Reimann. 1982. Isolation of human platelet membrane microparticles from plasma and serum. Blood. 60:834-840.

12. George, J. N. 1985. The role of membrane glycoproteins in platelet formation, circulation, and senescence. Review and hypotheses. In Platelet Membrane Glycoproteins. J. N. George, A. T. Nurden, and D. R. Phillips, editors. Plenum, New York. 395-412. 
13. McEver, R. P., and M. N. Martin. 1984. A monoclonal antibody to a membrane glycoprotein binds only to activated platelets. J. Biol. Chem. 259:9799-9804.

14. Hsu-Lin, S.-C., C. L. Berman, B. C. Furie, D. August, and B. Furie. 1984. A platelet membrane protein expressed during platelet activation and secretion. J. Biol. Chem. 259:9121-9126.

15. Stenberg, P., R. P. McEver, M. A. Shuman, Y. V. Jacques, and D. F. Bainton. 1985. A platelet alpha-granule membrane protein (GMP140 ) is expressed on the plasma membrane after activation. J. Cell Biol. 101:880-886.

16. George, J. N., R. M. Lyons, and R. K. Morgan. 1980. Membrane changes associated with platelet activation. J. Clin. Invest. 66:1-9.

17. Phillips, D. R., L. K. Jennings, and H. R. Prasanna. 1980. Ca ${ }^{2+}$ mediated association of glycoprotein $\mathrm{G}$ (thrombin-sensitive protein, thrombospondin) with human platelets. J. Biol. Chem. 255:11629-11632.

18. George, J. N., and A. R. Onofre. 1982. Human platelet surface binding of endogenous secreted Factor VIII-von Willebrand factor and platelet factor 4. Blood. 59:194-197.

19. Ginsberg, M. H., R. G. Painter, J. Forsyth, C. Birdwell, and E. F. Plow. 1980. Thrombin increases expression of fibronectin antigen on the platelet surface. Proc. Natl. Acad. Sci. USA. 77:1049-1053.

20. Hourdille, P., M. Hasitz, F. Belloc, and A. T. Nurden. 1985. Immunocytochemical study of the binding of fibrinogen and thrombospondin to ADP- and thrombin-stimulated human platelets. Blood. 65:912-920.

21. Mosher, D. F., D. M. Presciotta, J. C. Loftus, and R. M. Albrecht. 1985. Secreted alpha granule proteins: the race for receptors. In Platelet Membrane Glycoproteins. J. N. George, A. T. Nurden, and D. R. Phillips, editors. Plenum, New York. 171-191.

22. George, J. N., L. L. Thoi, and R. K. Morgan. 1981. Quantitative analysis of platelet membrane glycoproteins: effect of platelet washing procedures and isolation of platelet density subpopulations. Thromb. Res. 23:69-77.

23. Montgomery, R. R., T. J. Kunicki, C. Taves, D. Pidard, and M. Corcoran. 1983. Diagnosis of Bernard-Soulier syndrome and Glanzmann's thrombasthenia with a monoclonal assay on whole blood. $J$. Clin. Invest. 71:385-389.

24. Kunicki, T. J. 1985. Organization of glycoproteins within the platelet plasma membrane. In Platelet Membrane Glycoproteins. J. George, A. Nurden, and D. Phillips, editors. Plenum, New York. 87103.

25. Okita, J. R., D. Pidard, P. J. Newman, R. R. Montgomery, and T. J. Kunicki. 1985. On the association of glycoprotein Ib and actinbinding protein in human platelets. J. Cell Biol. 100:317-321.

26. McEver, R. P., E. M. Bennett, and M. N. Martin. 1983. Identification of two structurally and functionally distinct sites on human platelet membrane glycoprotein IIb-IIIa using monoclonal antibodies. J. Biol. Chem. 258:5269-5275.

27. McEver, R. P., N. L. Baenziger, and P. W. Majerus. 1980. Isolation and quantitation of the platelet membrane glycoprotein deficient in thrombasthenia using a monoclonal hybridoma antibody. J. Clin. Invest. 66:1311-1318.

28. Newman, P. J., R. W. Allen, R. A. Kahn, and T. J. Kunicki. 1985. Quantitation of membrane glycoprotein IIIa on intact human platelets using the monoclonal antibody, AP-3. Blood. 65:227-232.

29. Kieffer, N., A. Bourgois, and A. T. Nurden. 1985. Binding of released thrombospondin to human platelets. Thromb. Haemostasis. 54:218 (Abstr.)

30. Lawler, J. W., H. S. Slayter, and J. E. Coligan. 1978. Isolation and characterization of a high molecular weight glycoprotein from human blood platelets. J. Biol. Chem. 253:8609-8616.

31. Lawler, J., L. H. Derick, J. E. Connally, J.-H. Chen, and F. C. Chao. 1985. The structure of human platelet thrombospondin. J. Biol. Chem. 260:3762-3772.

32. Pidard, D., R. R. Montgomery, J. S. Bennett, and T. J. Kunicki. 1983. Interaction of AP-2, a monoclonal antibody specific for the human platelet glycoprotein IIb-IIIa complex, with intact platelets. J. Biol. Chem. 258:12582-12586.
33. Lichtman, M. A., and R. I. Weed. 1969. The monovalent cation content and adenosine triphosphatase activity of human normal and leukemic granulocytes and lymphocytes: relationship to cell volume and morphologic age. Blood. 34:645-660.

34. Jaffe, E. A., R. L. Nachman, C. G. Becker, and C. R. Minick. 1973. Culture of human endothelial cells derived from umbilical veins. J. Clin. Invest. 52:2745-2756.

35. George, J. N., R. D. Potterf, P. C. Lewis, and D. A. Sears. 1976. Studies on platelet plasma membranes. I. Characterization of surface proteins of human platelets labeled with diazotized [ $\left.{ }^{125} \mathrm{I}\right]$ diiodosulfanilic acid. J. Lab. Clin. Med. 88:232-246.

36. Tollefsen, D. M., J. R. Faegler, and P. W. Majerus. 1974. The binding of thrombin to the surface of human platelets. J. Biol. Chem 249:2646-2651.

37. Levine, S. P., and L. $\dot{S}$. Krentz. 1977. Development of a radioimmunoassay for human platelet factor 4. Thromb. Res. 11:673-686.

38. Bell, R. C., J. J. Coalson, J. D. Smith, and W. G. Johanson, Jr. 1983. Multiple organ system failure and infection in adult respiratory distress syndrome. Ann. Intern. Med. 99:293-298.

39. Snedecor, G. W., and W. G. Cochran. 1967. Statistical Methods. Iowa State University Press, Ames, IA. 6th edition. pp. 59-60.

40. Cosgrove, L. J., M. S. Sandrin, P. Rajasekariah, and I. F. C. McKenzie. 1986. A genomic clone encoding the $\alpha$-chain of the OKM1, LFA-1, and platelet glycoprotein IIb-IIIa molecules. Proc. Soc. Natl. Acad. Sci. USA. 83:752-756.

41. Thiagarajan, P., S. S. Shapiro, E. Levine, L. DeMarco, and A. Yalcin. 1985. A monoclonal antibody to human platelet glycoprotein IIIa detects a related protein in cultured endothelial cells. J. Clin. Invest. 75:896-901.

42. Fitzgerald, L. A., I. F. Charo, and D. R. Phillips. 1985. Human and bovine endothelial cells synthesize membrane proteins similar to human platelet glycoproteins IIb and IIIa. J. Biol. Chem. 260:1089310896.

43. Jaffe, E. A., J. T. Ruggiero, and D. J. Falcone. 1985. Monocytes and macrophages synthesize and secrete thrombospondin. Blood. 65: 79-84.

44. Hunter, N. R., J. Dawes, I. R. MacGregor, and D. S. Pepper. 1984. Quantitation by radioimmunoassay of thrombospondin synthesized and secreted by human endothelial cells. Thromb. Haemostasis. 52:288291.

45. Beckstead, J. H., P. E. Stenberg, R. P. McEver, M. A. Schuman, and D. F. Bainton. 1986. Immunohistochemical localization of membrane and $\alpha$-granule proteins in human megakaryocytes: application to plastic-embedded bone marrow biopsy specimens. Blood. 67:285-293.

46. Bouvier, C. A.; E. Gaynor, J. R. Cintron, B. Bernhardt, and T. H. Spaet. 1970. Circulating endothelium as an indication of vascular injury. Thromb. Diath. Haemorrh. (Suppl.) 40:163-168.

47. Hladovec, J., and P. Rossman. 1973. Circulating endothelial cells isolated together with platelets and the experimental modification of their counts in rats. Thromb. Res. 3:665-674.

48. Shuman, M. A., and S. P. Levine. 1980. Relationship between secretion of platelet factor 4 and thrombin generation during in vitro blood clotting. J. Clin. Invest. 65:307-313.

49. Levine, S. P., A. J. Suarez, R. R. Sorenson, L. K. Knieriem, and N. M. Raymond. 1981. The importance of blood collection methods for assessment of platelet activation. Thromb. Res. 24:433-443.

50. Solum, N. O., I. Hagen, C. Filion-Myklebust, and T. Stabaek. 1980. Platelet glycocalicin. Its membrane association and solubilization in aqueous media. Biochim. Biophys. Acta. 597:235-246.

51. Solum, N. O., T. M. Olsen, G. O. Gogstad, I. Hagen, and F. Brosstad. 1983. Demonstration of a new glycoprotein Ib-related component in platelet extracts prepared in the presence of leupeptin. Biochim. Biophys. Acta. 729:53-61.

52. Tocantins, L. M. 1943. Demonstration of antithromboplastic activity in normal and hemophilic plasmas. Am. J. Physiol. 139:265279.

53. Bennett, J. S., and G. Vilaire. 1979. Exposure of platelet fibrinogen receptors by ADP and epinephrine. J. Clin. Invest. 64:1393-1401. 
54. Heptinstall, S. 1976. The use of a chelating ion-exchange resin to evaluate the effects of the extracellular calcium concentration on adenosine diphosphate induced aggregation of human blood platelets. Thromb. Haemostasis. 36:208-220.

55. Fitzgerald, L. A., and D. R. Phillips. 1985. Calcium regulation of the platelet membrane glycoprotein IIb-IIIa complex. J. Biol. Chem. 260:11366-11374.

56. Pidard, D., D. Didry, T. J. Kunicki, and A. T. Nurden. 1986. Temperature-dependent effects of EDTA on the membrane glycoprotein IIb-IIIa complex and platelet aggregability. Blood. 67:604-611.

57. Kristopeit, S. M., and T. J. Kunicki. Quantitation of platelet membrane glycoproteins in Glanzmann's thrombasthenia and the Bernard-Soulier syndrome by electroimmunoassay. Thromb. Res. 36:133142.

58. Patzak, A., G. Bock, R. Fischer-Colbrie, K. Shauenstein, W. Schmidt, G. Lingg, and H. Winkler. 1984. Exocytotic exposure and retrieval of membrane antigens of chromaffin granules: quantitative evaluation of immunofluorescence on the surface of chromaffin cells. J. Cell Biol. 98:1817-1824.

59. Stenberg, P. E., M. A. Shuman, S. P. Levine, and D. F. Bainton. 1984. Redistribution of alpha-granules and their contents in thrombinstimulated platelets. J. Cell Biol. 98:748-760.

60. Coller, B. S. 1985. A new murine monoclonal antibody reports an activation-dependent change in the conformation and/or microenvironment of the platelet glycoprotein IIb/IIIa complex. J. Clin. Invest. 76:101-108.
61. George, J. N., R. M. Lyons, and R. K. Morgan. 1980. Membrane changes caused by platelet aggregation and secretion. In Platelets: Cellular Response Mechanisms and Their Biological Significance. A. Rotman, F. A. Meyer, C. Gitler, and A. Silverberg, editors. John Wiley and Sons, Chichester. 81-93.

62. Shukla, S. D., J. Berriman, R. Coleman, J. B. Finean, and R. H. Mitchell. 1978. Membrane protein segregation during release of microvesicles from human erythrocytes. Fed. Eur. Biochem. Soc. Lett. 90: 289-292.

63. Rotman, A., N. Makov, and E. F. Lüscher. 1982. Isolation and partial characterization of proteins from platelet pseudopods. Proc. Natl. Acad. Sci. USA. 79:4357-4361.

64. Harker, L. A., T. W. Malpass, H. E. Branson, E. A. Hassell II, and S. J. Slichter. 1980. Mechanism of abnormal bleeding in patients undergoing cardiopulmonary bypass: acquired transient platelet dysfunction associated with selective $\alpha$-granule release. Blood. 56:824-834.

65. Musial, J., S. Niewiarowski, D. Hershock, T. A. Morinelli, R. W. Colman, and L. H. Edmunds, Jr. 1985. Loss of fibrinogen receptors from the platelet surface during simulated extracorporeal circulation. $J$. Lab. Clin. Med. 105:514-522.

66. Kowalski, E. 1968. Fibrinogen derivatives and their biologic significance. Semin. Hematol. 5:45-59.

67. Coller, B. S., and L. E. Scudder. 1985. Inhibition of dog platelet function by in vivo infusion of $\mathrm{F}\left(\mathrm{ab}^{\prime}\right)_{2}$ fragments of a monoclonal antibody to the platelet glycoprotein IIb-IIIa receptor. Blood. 66:1456-1459. 